Jurnal Indonesia Sosial Teknologi:p-ISSN: 2723 - 6609

e-ISSN :2745-5254

Vol. 3, No.1 Januari 2022

\title{
USABILITY WEB PADA WEBSITE D2MART.ID
}

\section{Ayu Sulistiawati ${ }^{1}$, Adi Hermawansyah ${ }^{2}$, Erlin Setyaningsih ${ }^{3}$}

Jurusan Sistem Informasi, Stmik Borneo Internasional Balikpapan ${ }^{1,2,3}$

Email: ayu_sulistiawati.17@stmik-borneo.ac.id ${ }^{1}$, adi.hermawansyah26@gmail.com²

erlin_setyaningsih@stmik-borneo.ac.id ${ }^{3}$

\begin{abstract}
Abstrak
Website d2mart.id adalah sebuah website yang digunakan sebagai wadah penjualan online di Desa Bangun Mulya Kecamatan Waru Kabupaten Penajam Paser Utara. Pada penelitian ini bertujuan untuk mengetahui tingkat penggunaan dan kepuasan pengguna pada aplikasi website D2mart.id di Desa Bangun Mulya Kecamatan Waru. adapun metode yang digunakan adalah kualitatif deskriftif dengan responden sebanyak 100 orang yang berasal dari peserta sosialisasi website D2mart.id dengan menggunakan instrument penelitian yaitu usability testing, wawancara dan kuesioner, yang mana kuesioner tersebut merupakan kuesioner pilihan untuk mengukur usability yakni menggunakan kuesioner PSSUQ (Post- Study System Quesionnaire). Berdasarkan hasil penelitian diperoleh antaralain bahwa fitur iklan tidak dapat langsung terhubung ke facebook atau instagram dan verifikasi data terasa rumit serta hasil evaluasi dari usability testing dengan 5 partisipan yang telah mengerjakan 4 tugas skenario didapatkan hasil komponen efficiency sebesar 0,023 goalsatausec, komponen error 7,7\% per tugas, komponen satification menggunakan kuesioner PSSUQ dengan nilai rata-rata 5. Serta hasil wawancara terdapat 5 partisipan yang mengalami 6 masalah yang berbeda mereka alami. Maka dapat diambil kesimpulan dari unsur satisfaction dan wawancara bahwa website d2mart.id dengan hasil agak setuju namun perlu perbaikan dan pengembangan lebih lanjut.
\end{abstract}

Kata kunci: Usability testing; Website; PSSUQ (Post-Study System Usability Questionnaire).

\section{Abstract}

Website d2mart.id is a website to us as a place to online selling in Bangun mulya village of warudistrict at the penajam paser utara regency this is research has the objective to know the usage level and the user satisfaction in the website d2mart.id the method of research is used the descriftive Qualitative with one hundred respondens is from the sosialization partisipans of website d2mart.id with the instrument using of reseach is usability testing interview and quesionairre that is the quesionaire is to choosing questioner to measure the usability is used the PSSUQ (post study) basedon the result of the research good as follows the advertaising is can not direct to connect of facebook or instagram and data verification is still complecable and the evaluation result from usability testing with five partisipants had been done for scenario job is getting the result from efficiency component is 0,023 percentage, error component 7.7 percentage per job satisfication component PSSUQ with theaverage point is five. The result is got from five partisipants that is done six 
differents problem theirhappened so it is to take the consolution from satisfaction and interview so the website d2mart.id withthe results enaught aggrement but it needs repairing and developing to the next

Keywords: Usability testing; Website; PSSUQ (Post-Study System Usability Questionnaire).

\section{Pendahuluan}

Perkembangan teknologi informasi banyak mengakibatkan perkembangan informasi semakincepat dan pesat (Elisabeth, 2019). Tidak terkecuali bidang UMKM, peran UMKM dalam perekonomian sebuah Negaramenjadi penting karena tidak dapat dipisahkan dari upaya para stakeholder terkait untuk mewujudkan pertumbuhan dan mengangkat kesejehteraan para pelaku UMKM (HIDAYAH \& Subhan, 2019). Salah satu indikator dalam peningkatan kesejehteraan pelaku UMKM adalah dengan meningkatnya omset penjualan (Hapsoro, Palupiningdyah, \& Slamet, 2019). Kondisi inidiharapkan dapat tercapai dengan memaksimalkan strategi pemasaran digital, yang didesain khusus untuk para pelaku UMKM di Desa Bangun Mulya Kecamatan Waru. Hal ini menjadi penting, karena percepatan teknologi yang bergerak sangat cepat, menyebabkan perubahan perilaku konsumen dalammemilih dan melakukan transaksi jual-beli (Aulia, 2020). Situasi inilah yang mendorong pelaku UMKM harus mampu berbenah dan melakukan inovasi, untuk tidak hanya sekedar untuk bertahan tetapi juga mampumenikmati keuntungan finansial dari perubahan teknologi yang terjadi pada saat ini (Aditi, Hermansyur, Hafizah, \& Tamba, 2019).

Pelaku UMKM yang ada Penajam Paser Utara sangat banyak dari berbagai wilayah namun diDesa Bangun Mulya tepat berada Kecamatan Waru di Kabupaten Penajam Paser Utara KalimantanTimur. Desa ini terdiri dari 3 (tiga) dusun yang masing - masing dusun dipimpin oleh seorang kepaladusun sebagai penyambung suara warga kepada pihak pemerintah desa. Dengan jumlah warga kuranglebih 5000 orang yang terbagi dalam 16 Rukun tetangga. Adapun mata pencaharian di Tiga dusun iniadalah banyak yang berprofesi sebagai petani dan usaha swasta, UMKM yang bergerak dalam usahamikro pembuatan makan olahan keripik singkong, ubi, talas, kulit singkong, keripik daun bayam, dan lainnya yang kesemuanya itu banyak dilakukan oleh perempuan yang ingin membantu dalam rangka peningkatan ekonomi terkhusus untuk mencukupi kebutuhan keluarga.

Menurut Lembaga pelaku UMKM yang ada di Kecamatan Waru ada di Desa Bangun Mulya namun perlu memanfaatkan teknologi informasi dan telah menjadi suatu kebutuhan untuk menunjang prosesbisnis UMKM. Melihat keadaan yang terjadi di atas Program Studi Sistem Informasi STMIK BorneoInternasional sebagai salah satu unit jasa pendidikan mendapat tantangan dan peluang untuk memanfaatkan potensi yang dimiliki untuk dapat membantu dan meluangkan kesempatan pemikiran dan kemampuan pendidikan untuk membangun website D2mart.id Desa Bangun Mulya Kecamatan Waru. 
Dengan adanya Program Holistik Pembinaan dan Pemberdayaan Desa (PHP2D) maka mahasiswa/i membuat program dan terbentuklah website $\mathrm{d} 2 \mathrm{mart}$.id, merupakan website yang diciptakan oleh Mahasiswa/i dari STMIK Borneo Internasional yang mengikuti Program Holistik Pembinaan dan Pemberdayaan Desa (PHP2D) yakni sasarannya untuk Desa Bangun Mulya KecamatanWaru, terkait peluang besar bagi mahasiswa/i atas dukungan dari Desa Bangun Mulya serta kebutuhanbagi masyarakat yang membutuhkan pemberdayaan desa di bidang UMKM, maka Mahasiswa/i berinisiatif untuk melakukan Program Holistik Pembinaan dan Pemberdayaan Desa (PHP2D) di desatersebut (Kelana et al., 2020).

Manfaat Aplikasi diukur berdasarkan parameter-parameter kepuasan pengguna (User Satisfaction) terhadap aplikasi. Kecenderungan sikap penolakan atau penerimaan terhadap aplikasi melalui kegiatan survei diharapkan dapat memberikan masukan untuk penyempurnaan aplikasi ini dikemudian hari. Saat ini banyak sekali website yang menyajikan beragam informasi. Namun demikian, banyak pula di antara website tersebut yang tidak dapat memenuhi tujuan awal kenapa website tersebut dibuat dan bahkan sangat banyak yang mengecewakan pengguna yang mengaksesnya (Yadi, 2018).

Usability berasal dari kata usable yang secara umum berarti dapat digunakan dengan baik (Ariantoro, 2017). Sesuatu dapat dikatakan berguna dengan baik apabila kegagalan dalam penggunaannya dapat dihilangkan atau diminimalkan serta memberi manfaat dan kepuasan kepada pengguna (Yuliyana, Arthana, \& Agustini, 2019).

Tujuan dari Usability testing merupakan sebuah teknik pengukuran untuk mengetahui pengguna dapat menggunakan sistem website dengan mudah dan seberapa effisien dan efektif dalam sebuah sistem dapat membantu pengguna untuk mencapai tujuannya.

\section{Metode Penelitian}

Dalam penelitian ini langkah pertama yang dilakukan yaitu studi literature terlebih dahulu, studi litertur yang dilakukan terhadap teori-teori atapun metode-metode yang relevan pada penelitian ini (Sugiyono, 2012). Studi literatur yang dimaksud pada penelitian ini yaitu jurnal-jurnal, laporan penelitian, dan buku. Selanjutnya melaksanakan evaluasi yang dimulai dari menentukan siapa saja partisipan yang akan menjadi objek penelitian dan mempersiapkan serta merancang tugas skenario yang akan di uji. Selanjutnya melaksanakan evaluasi yaitu pertama melakukan usability testing selanjutnya melakukan wawancara kepada partisipan dan dilanjutkan denga pembagian kuesioner PSSUQ terhadap responden, setelah melakukan pelaksanaan evaluasi maka peneliti melanjutkan tahapan penelitian yaitu menganalisis dan melakukan pembahasan serta tahapan terakhir yaitupeneliti dapat menarik kesimpulan dan saran, seperti pada gambar 3.1 Tahapan Penelitian sebagai berikut : 


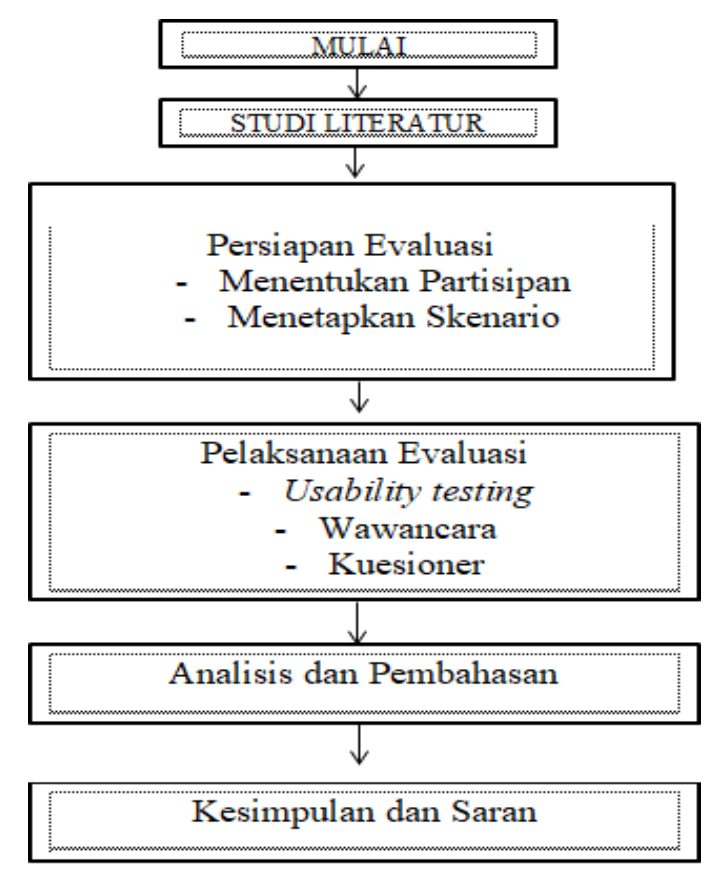

3.1 Tahapan Penelitian

Dalam penelitian ini menggunakan metode Usability testing berdasarkan usability testing yaitu dengan menentukan evaluator, melakukan survey dengan kuesioner, melakukanpemilihan fungsi, membuat usability testing, menyusun skrip usability test, melaksanakan usability testing dengan melakukan wawancara, melakukan analisa data dari hasil usability test dan survey, menyusun rekomendasi perbaikan aplikasi merupakan tahap-tahap yang dilakukan dalam penelitian usability testing. Subjek dan objek didalam penelitian ini adalah masyarakat umum Desa Bangun Mulya Kecamatan Waru Kabupaten Penajam Paser Utara dengan melibatkan masyarakat untuk mengetahui usability website pada website D2mart.id untuk diketahui saran perbaikan pada website tersebut.

Pada umumnya pengukuran usability dilakukan dengan serangkaian kuesioner. Adabeberapa jenis kuesioner yang dapat digunakan untuk mengukur usability sebagai berikut :

1. System Usability Scale (SUS), yang ditawarkan secara komersial dalam bentuk paket.

2. System Usability Measurement Inventory (SUMI)

3. Questionnaire for User Interaction Satisfaction (QUIS)

4. Post Study System Usability Quesionnaire (PSSUQ)

5. Standartized Universal Percentile Rank Quesionnaire (SUPR-Q)

Berdasarkan beberapa jenis kuesioner yang dapat digunakan untuk mengukur usability diatas maka kuesioner yang digunakan pada penelitian ini adalah Post Study System Usability Quesionnaire (PSSUQ). PSSUQ terdiri dari 19 pernyataan dari kuesioner danmemiliki 7 tingkatan tanggapan, yaitu sangat tidak setuju, tidak setuju agak tidak setuju, netral, agak setuju, setuju dan sangat setuju. 


\section{Hasil dan Pembahasan}

Dari penggunaan data yang di gunakan merupakan data dari responden yang telah mengisi kuisioner.

\section{Tabel 1 Profil Berdasarkan Jenis Kelamin}

\begin{tabular}{ccc}
\hline Jenis & $\begin{array}{c}\text { Jumlah } \\
\text { Kesponde } \\
\text { nelamin }\end{array}$ & $\begin{array}{c}\text { Persentas } \\
\text { e }\end{array}$ \\
\hline Laki-laki & 43 & $43 \%$ \\
Perempuan & 57 & $57 \%$ \\
Total & 100 & $100 \%$ \\
\hline
\end{tabular}

Sumber : Hasil Pengelolaan Data Berdasarkan Kuisioner

Berdasarkan tabel tersebut dapat diketahui bahwa sebagian besar responden pada penelitian ini berjenis kelamin perempuan yang berjumlah 57 atau dapat dikatakan 57\% dari total 100 dan responden laki-laki sebanyak 43 atau $43 \%$.

\section{Jenis Kelamin}

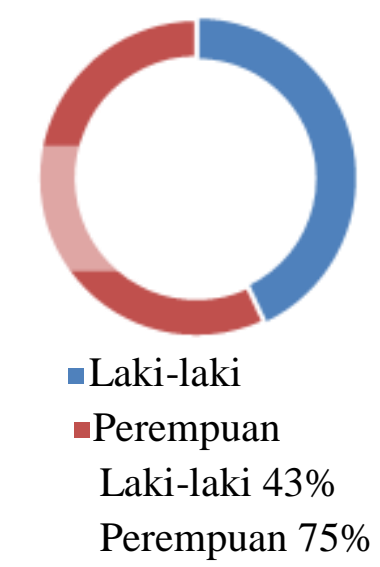

Gambar 1 Diagram Profil Responden Berdasarkan Jenis Kelamin

Pengujian yang di lakukan pada penelitian ini dimulai dari bulan april sampai denganbulan mei 2021 dan berlokasi di Desa Bangun Mulya Kecamatan Waru, dimana penelitian dilakukan 5 partisipan untuk usability testing dan 100 responden untuk wawancara serta pembagian kuesioner yang sesuai dengan metode pada penelitian ini. Dari sistematis peneliti melakukan penilaian keberhasilan dari tugas-tugas yang dilakukan oleh partisipan dengan penilaian berhasil atau tidak berhasilnya sebuah tugas yang diberikan kepada partisipan.

Tabel 2 Hasil Penilaian Pengerjaan Tugas Skenario

\begin{tabular}{cccll}
\hline $\begin{array}{c}\text { PARTISIP } \\
\text { AN }\end{array}$ & TUGAS 1 & TUGAS 2 & TUGAS 3 & TUGAS 4 \\
\hline P1 & Sukses & Sukses & Sukses & Sukses \\
\hline P2 & Sukses & Sukses & Sukses & Sukses \\
\hline
\end{tabular}




\begin{tabular}{lllll}
\hline P3 & Sukses & Sukses & Sukses & Sukses \\
\hline P4 & Sukses & Sukses & Gagal & Sukses \\
\hline P5 & Sukses & Sukses & Sukses & Sukses \\
\hline
\end{tabular}

Dari tabel 3.2 maka dapat disimpulkan bahwa hasil dari penelitian pengerjaan tugas skenario menyatakan bahwa semua partisipan berhasil dalam menjalankan tugas dengansukses kecuali partisipan keempat gagal menyelesaikan tugas 3 .

\section{Komponen Efficiency}

Pada komponen efficiency merupakan waktu yang dubutuhkan oleh partisipan untuk menyeselsaikan tugas-tugas pada skenario tugas akan direkam (Trilestari, AzZahra, \& Wijoyo, 2019). Pada waktu yang terhitung maka dimulai dan peneliti membacakan tugas sehingga pasrtisipan dapat menyelesaikantugas yang telah diberikan peneliti, maka seluruh waktu yang di butuhkan oleh partisipan dalam pengujian tugas skenario akan dicatat oleh peneliti, termasuk partisipan yang sukses ataupun gagal dalam menjalankan tugas skenario. Perhitungan waktu ynag digunakan pada penelitian ini untuk menjalankan skenario tugas dalam satuan detik.

Pada waktu penyelesaian tugas skenario mulai dihitung pada saaat peneliti selesai memberikan tugas pada partisipan mulai menggunakan website d2mart.id. Ketika partisipan telah selesai melakukan tugas yang telah diberikan maka perhitungan waktu akan selesai, atapun partisipan telah menyerah menyelesaikan tugas yang telah diberikan. Berdasar kantabel 4.3 menunjukan waktu yang telah digunakan oleh partisipan dalam penyelesaian tugas(satuan detik).

Tabel 3 Waktu yang dibutuhkan pasrtisipan menyelesaikan tugas (satuan detik)

\begin{tabular}{ccccc}
\hline $\begin{array}{c}\text { PARTISIPA } \\
\text { N }\end{array}$ & TUGAS 1 & TUGAS 2 & TUGAS & TUGAS \\
\hline P1 & & & $\mathbf{3}$ & $\mathbf{4}$ \\
\hline P2 & 46 & 39 & 29 & 71 \\
\hline P3 & 130 & 64 & 45 & 99 \\
\hline P4 & 42 & 44 & 44 & 37 \\
\hline P5 & 72 & 39 & 21 & 81 \\
\hline Rata-rata & 66,6 & 43,2 & 34,6 & 67 \\
\hline
\end{tabular}

Pada komponen efficiency menggunakan perhitungan Time Based Efficiency gunauntuk mengukur kecepatan penguna atau speed of work saat menjalankan tugas skenario yang telah diberikan oleh peneliti.

Berdasarkan total tugas skenario yang diselesaikan oleh partisipan sebanyak 20 skenario tugas dan total partisipan yaitu 5, maka terdapat tugas diantaranya 19 berhasil diselesaikan dengan sukses, dan 1 gagal diselesaikan. Sehingga pada perhitungan time base efficiency (menggunakan persamaan 1), mendapatkan hasil nilai efficiency sesuai 
dengan kecepatan partisipan dalam menyelesaikan tugas skenario sebesar 0,023 Goals/sec.

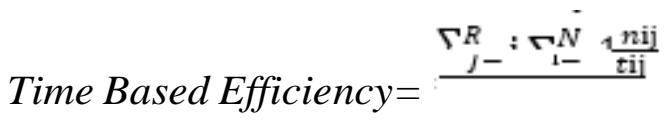

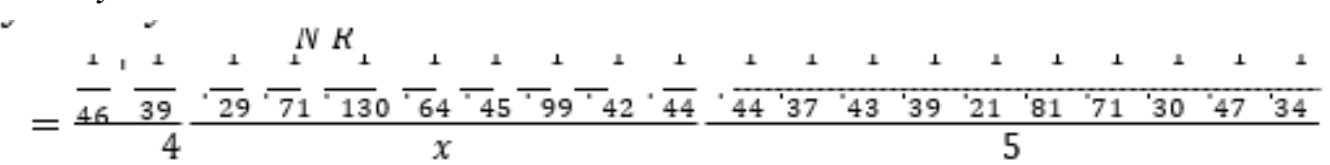

$$
\begin{aligned}
& =0.023 \text { goals } / \mathrm{sec}
\end{aligned}
$$

\section{Komponen Errors}

Pada komponen errors ini yaitu berdasarkan jumlah kesalahan yang telah dilakukan oleh partisipan ketika menjalankan tugas skenario yang diberikan oleh peneliti. Untuk melakukan pengukuran pada komponen errors maka terlebih dahulu memperhatikan kesempatan (opportunity) yang akan dilalui oleh partisipan ketika mengerjakan skenario tugas, selanjutnya menghitung kesalahan yang dilakukan oleh partisipan pada penyelesaian setiap tugas. Pada tugas pertama memiliki opportunity sebanyak 6 Pada tugas kedua memiliki opportunity sebanyak 7 Pada tugas ketiga memiliki opportunity sebanyak 6 Pada tugaskeempat memiliki opportunity sebanyak 7. Apabila partisipan melewati langkah atau proses penyelesaian tugas, maka partisipan dianggap melalukan kesalahan meskipun pada dasarnya partisipan dapat menjalankan suatu langkah, namun partisipan melakukan pada saat tugas. Hasil dari tingkat errors pada website $\mathrm{d} 2$ mart.id dapat dilihat pada tabel 4 sebagai berikut.

Tabel 4 Jumlah kesalahan oleh penggunaatau partisipan

\begin{tabular}{lllll}
\hline $\begin{array}{l}\text { PARTISIPA } \\
\text { N }\end{array}$ & TUGAS 1 & TUGAS 2 & TUGAS 3 & $\begin{array}{l}\text { TUGA } \\
\text { S 4 }\end{array}$ \\
\hline $\mathrm{P} 1$ & 0 & 0 & 0 & 0 \\
\hline $\mathrm{P} 2$ & 0 & 0 & 0 & 5 \\
\hline $\mathrm{P} 3$ & 0 & 1 & 0 & 1 \\
\hline $\mathrm{P} 4$ & 1 & 0 & 0 & 2 \\
\hline $\mathrm{P} 5$ & 1 & 0 & 0 & 0 \\
\hline Total & 2 & 1 & 0 & 8 \\
\hline
\end{tabular}

Untuk menghitung sebuah errors maka dibutuhkannya perhitungan dilakukan denganpada setiap tugas skenario dengan persamaan 2 sebagai berikut :

Errors $=\frac{\text { Total } \text { errors }}{\text { Total } \text { opportunity }}$

Keterangan :

Total errors $=$ Total kesalahan yang dilakukan oleh pengguna (partisipan)

Total opportunity $=$ Total langkah kesempatan yang dimiliki oleh skenario tugas 
Berdasarkan Tabel 3.4 Jumlah kesalahan oleh pengguna atau partisipan maka dapat disimpulkan bahwa partisipan pertama tidak pernah melakukan kesalahan atau 0 kesalahan sedangkan partisipan kedua menjadi yang paling banyak melakukan kesalahan yaitu total 5 kesalahan maka dapat dilihat dengan persamaan 2 akan mendapatkan hasil komponenen errors pada tabel 3.5 sebagai berikut:

Tabel 5 Perhitungan errors

\begin{tabular}{|c|c|}
\hline $\begin{array}{l}\text { Tuga } \\
\text { s }\end{array}$ & Perhitungan \\
\hline Tugas 1 & $\begin{aligned} \text { Errors }= & 2=0,06=6 \% \\
& 6 \times 5\end{aligned}$ \\
\hline Tugas 2 & $\begin{aligned} \text { Errors }= & \begin{array}{l}1=0,028=2,8 \% \\
7\end{array} 75\end{aligned}$ \\
\hline Tugas 3 & 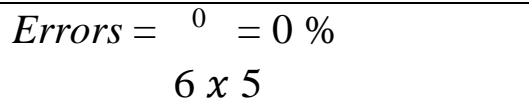 \\
\hline Tugas 4 & $\begin{array}{c}\text { Errors }={ }^{8}=0,22=2,2 \% \\
7 \times 5\end{array}$ \\
\hline
\end{tabular}

Berdasarkan hasil dari komponen errors maka dapat disimpulkan bahwa pada website $\mathrm{d} 2$ mart.id memiliki kesalahan $7,7 \%$ per skenario tugas, yang berarti masih sangat baik namun kesalahan ini juga memacu untuk perbaikan pada website d2mart.id.

\section{Kuesioner PSSUQ}

Dari hasil penyebaran kuesioner yang dilakukan oleh peneliti dengan 100 responden Kemudian dari pernyataan U1 - U19 yang mana merupakan pernyataan PSSUQ dengan 7

poin alternatif yaitu yaitu sangat tidak setuju, tidak setuju, agak tidak setuju, netral, agak setuju dan sangat setuju, dimana aturannya skala point 1 merupakan (paling rendah) danpoint 7 merupakan nilai (paling tinggi) dengan aturan yang ada sehingga semakin tinggi nilai PSSUQ maka semakin baik. Berdasarkan hasil PSSUQ di bagi manjadi 4 kelompok yaitu OVERALL, SYSUSE, INFOQUAL dan INTERQUAL

Berdasarkan hasil kuisioner yang didapatkan sehingga di dapatkan nilai ratarata perjenis Tanggapan PSSUQ sepeti di Gambar 3.2 sebagai berikut : 


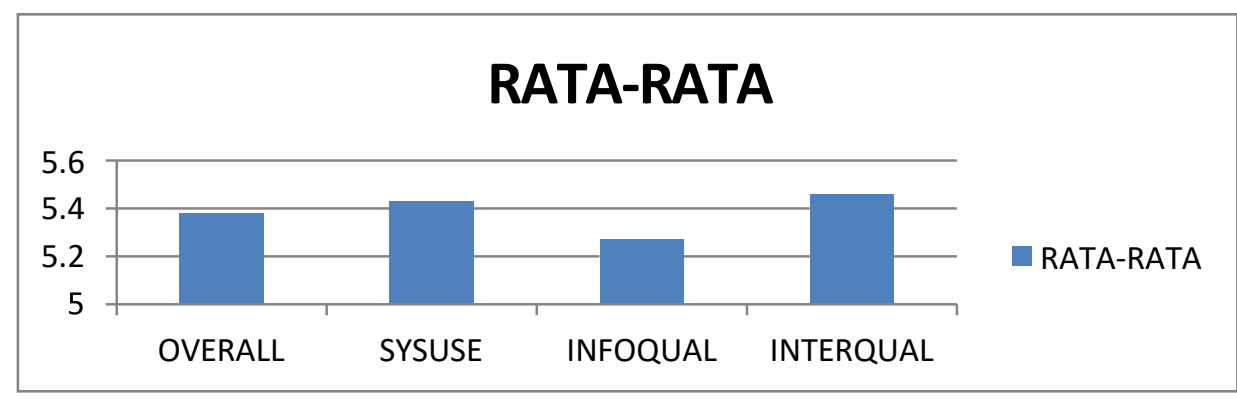

Gambar 2 Nilai Rata-Rata Per Jenis Tanggapan Pssuq

Hasil kuesioner yang didapatkan berdasarkan Gambar 3.2 menunjukan hasil ratarataberdasarkan 4 komponen PSSUQ dari grafik terlihat bahwa :

Secara OVERALL (keseluruhan) dari 1-16 pernyataan memiliki rata-rata skor 5,38 yang berarti berdasarkan skala 7 point para responden memilih agak setuju, secara SYSUSE (Kepuasan Pengguna terhadap kualitas sistem) memiliki rata-rata 5,43 yang berarti berdasarkan skala 7 point para responden memilih agak setuju, selanjutnya untuk pointINFOQUAL (Kepuasan pengguna pada kualitas informasi) memiliki rata-rata 5,27 yang berarti berdasarkan skala 7 point para responden memilih agak setuju dan secara INTQUAL (kepuasan pengguna terhadap kualitas tampilan) memiliki rata-rata 5,46 yang berarti berdasarkan skala 7 point para responden memilih agak setuju

\section{Hasil Wawancara}

Berdasarkan hasil wawancara yang dilakukan oleh peneliti guna untuk menggali permasalah dan informasi lainnya yang tidak dapat diketahui ataupun tidak terlihat pada saat melakukan pengujian melalui pengujian tugas skenario. Didapatkan total 5 permasalahan yang dialami oleh partisipan yang tidak di ketahui ketika melalukan pengujian tugas skenario.Permasalahan tersebut dapat dilihat pada tabel 4.6 sebagai berikut :

Tabel 6 Permasalahan-permasalahan hasil wawancara

\begin{tabular}{|c|c|}
\hline Permasalahan & Jumlah Peserta \\
\hline Fitur promo atau diskon tidak ada & 3 \\
\hline Ukuran text kurang besar & 2 \\
\hline $\begin{array}{l}\text { Tidak ada fitur terhubung ke } \\
\text { Facebookatau instagram }\end{array}$ & 5 \\
\hline Alur verifikasi data terasa rumit & 4 \\
\hline Kurang banyaknya kategori pada website & 3 \\
\hline $\begin{array}{l}\text { Bagian fitur penjualan kurang } \\
\text { informative } \\
\text { (tidak update stock) }\end{array}$ & 3 \\
\hline
\end{tabular}

Dari permasalahan diatas maka dapat disimpulkan bahwa permasalahan yang paling banyak dialami adalah 5 dari 5 partisipan yang menyatakan bahwa tidak ada fitur 
terhubung langsung ke facebook serta instagram yang membuat para pelaku UMKM harus melakukan penjualan manual kembali di facebook dan instagram. 4 partisipan juga merasakan bahwa alur verifikasi data terasa rumit, sehingga dapat menjadi perhatian untuk pengembangan website $\mathrm{d} 2$ mart.id kedepannya.

\section{Hasil Kuesioner PSSUQ}

Dari hasil penyebaran kuesioner yang dilakukan oleh peneliti dengan 100 responden Kemudian dari pernyataan U1 - U19 yang mana merupakan pernyataan PSSUQ dengan 7 poin alternatif yaitu yaitu sangat tidak setuju, tidak setuju, agak tidak setuju, netral, agak setuju dan sangat setuju, dimana aturannya skala point 1 merupakan (paling rendah) danpoint 7 merupakan nilai (paling tinggi) dengan aturan yang ada sehingga semakin tinggi nilai PSSUQ maka semakin baik. Berdasarkan hasil PSSUQ di bagi manjadi 4 kelompok yaitu Overall, Sysue, Infoqal Dan Interqual.

Tabel 7 Nilai Rata-Rata Tanggapan Pssuq

\begin{tabular}{|l|c|c|c|c|}
\hline & OVERALL & SYSUSE & INFOQUAL & INTERQUAL \\
\hline RATA-RATA & 5.38 & 5.43 & 5.27 & 5.46 \\
\hline
\end{tabular}

Berdasarkan tabel di atas merupakan hasil olahan data Post-Study System Usability Questionnare (PSSUQ) yang diperoleh dan di analisa hasilnya, Sehingga skor yang di dapatkan pada Post-Study System Usability Questionnare (PSSUQ) Website D2mart.id berada pada penilaian yang positif karena berdasarkan tabel rata-rata menunjukkan angka lebih dari 5. Pada rata-rata secara keseluruhan ialah 5,38 untuk kegunaan sistem ialah 5,43 untuk kualitas informasi ialah 5,27 dan untuk kualitas antarmuka ialah 5,46 dan dari hasil wawancara yang dilakukan menemukan 6 masalah yang di alami oleh partisipan dengan masalah yang paling banyak adalah Tidak ada fitur terhubung ke Facebook atau instagram dan Alur verifikasi data terasa rumit.

Usability testing merupakan sebuah teknik pengukuran untuk mengetahui pengguna dapat menggunakan sistem website dengan mudah dan seberapa effisien dan efektif dalam sebuah sistem dapat membantu pengguna untuk mencapai tujuannya. Penelitian ini menggunakan usability testing sebagai pengukur sejauh mana tingkat kemudahan pengguna dalam menyelesaikan tugas ketika menggunakan website d2mart.id. Atribut usability dapat diukur dengan cara yaitu, tingkat kecepatan (efficiency) dalam mencari informasi yang dibutuhkan, tingkat kesalahan yang dilakukan oleh pengguna (errors) dan tingkat kepuasan pengguna (satisfaction) dengan mengunakan kuesioner Post-Study System Usability Questionnare (PSSUQ). Selain itu pada metode wawancara dilakukan untuk mengetahui seberapa tinggi potensi masalah yang terjadi pada para pengguna website $\mathrm{d} 2$ mart.id.

\section{Kesimpulan}

Berdasarkan wawancara dan observasi terdapat permasalahan di website d2mart.id yaitu bahwa fitur iklan pada website $\mathrm{d} 2$ mart.id tidak dapat langsung terhubung 
ke facebook atau instagram dan verifikasi data terasa rumit. Evaluasi usability testing berdasarkan dari 5 partisipan yang telah mengerjakan 4 tugas skenario didapatkan hasil komponen efficiency sebesar 0,023 goalsatausec, komponen error 7,7\% per tugas, komponen satification menggunakan kuesioner PSSUQ dengan nilai rata-rata 5 dimana Secara OVERALL (keseluruhan) dari 1-16 pernyataan memiliki rata-rata skor 5,38 yang berarti berdasarkan skala 7 point para responden memilih agak setuju, secara SYSUSE (Kepuasan Pengguna terhadap kualitas sistem) memiliki rata-rata 5,43 yang berarti berdasarkan skala 7 point para responden memilih agak setuju, selanjutnya untuk point INFOQUAL (Kepuasan pengguna pada kualitas informasi) memiliki rata-rata 5,27 yang berarti berdasarkan skala 7 point para responden memilih agak setuju dan secara INTQUAL (kepuasan pengguna terhadap kualitas tampilan) memiliki rata-rata 5,46 yang berarti berdasarkan skala 7 point para responden memilih agak setuju. Peneliti melakukan wawancara pada 5 partisipan dan memiliki 6 masalah yang mereka alami. Maka dapat disimpulkan bahwa dari segi satisfaction dan wawancara bahwa website d2mart.id sudah memuaskan para pengguna namun perlu perbaikan dan pengembangan selanjutnya. 


\section{Bibliografi}

Aditi, Bunga, Hermansyur, H. M., Hafizah, Hafizah, \& Tamba, Muller. (2019). Perlunya Inovasi, Kreativitas, Dan Pemasaran Online Dalam Meningkatkan Penjualan UMKM Penjahit Keriahen. Prioritas: Jurnal Pengabdian Kepada Masyarakat, $1(01), 42-51$.

Ariantoro, Tri Rizqi. (2017). Penerapan Metode Usability Pada Sistem Informasi Pelayanan Pelanggan (Studi Kasus: Website Pdam Tirta Musi Palembang). Prosiding Seminar Nasional Darmajaya, 1(1), 252-265. DOI: https://doi.org/10.30873/ji.v17i2.980

Aulia, Sisca. (2020). Pola Perilaku Konsumen Digital Dalam Memanfaatkan Aplikasi Dompet Digital. Jurnal Komunikasi, 12(2), 311-324. DOI: 10.24912/jk.v12i2.9829

Elisabeth, Duma Megaria. (2019). Kajian terhadap peranan teknologi informasi dalam perkembangan audit komputerisasi (studi kajian teoritis). METHOMIKA: Jurnal Manajemen Informatika \& Komputerisasi Akuntansi, 3(1), 40-53. DOI: https://doi.org/10.46880/jmika.Vol3No1.pp40-53

Hapsoro, Bayu Bagas, Palupiningdyah, Palupiningdyah, \& Slamet, Achmad. (2019). Peran digital marketing sebagai upaya peningkatan omset penjualan bagi klaster UMKM di Kota Semarang. Jurnal Abdimas, 23(2), 117-120.

HIDAYAH, SITI, \& Subhan, Subhan. (2019). Pemberdayaan Umkm (Usaha Mikro Kecil Dan Menengah) Melalui Psbi (Program Sosial Bank Indonesia) Bank Indonesia Kantor Pewakilan Wilayah Jambi. UIN Sulthan Thaha Saifuddin Jambi.

Kelana, Riefda Arya, Himawan, Riswanda, Trisanti, Anis Surya, Afrilia, Tika, Sari, Agelia, Tamaya, Ramadhani Inda, Widya, Piska Eka, Oktaviana, Diana, Ariani, Ajeng Retno, \& Widyaningrum, Atik. (2020).

Sugiyono. (2012). Metode Penelitian Kuantitatif, Kualitatif dan R \& D.Bandung:Alfabeta. Metode Penelitian Kuantitatif, Kualitatif Dan $R \&$ D.Bandung:Alfabeta.

Trilestari, Adelia Ayu, Az-Zahra, Hanifah Muslimah, \& Wijoyo, Satrio Hadi. (2019). Evaluasi Usability Aplikasi Digital Citizen Journalist Dengan Menggunakan Metode Usability Testing. Jurnal Pengembangan Teknologi Informasi Dan Ilmu Komputer E-ISSN, 2548, 964X.

Yadi, Yadi. (2018). Analisa Usability Pada Website Traveloka. JURNAL ILMIAH BETRIK: Besemah Teknologi Informasi Dan Komputer, 9(03), 172-180. DOI: https://doi.org/10.36050/betrik.v9i03.43

Yuliyana, Tifani, Arthana, I. Ketut Resika, \& Agustini, Ketut. (2019). Usability Testing pada Aplikasi POTWIS. JST (Jurnal Sains Dan Teknologi), 8(1), 12-22. 
Usability Web Pada Website D2mart.Id

DOI: http://dx.doi.org/10.23887/jst-undiksha.v8i1.12081 